Metabolism

Manuscript Number: DIABET-D-16-00160

Title: Risk of Type 2 Diabetes in Patients with Non-Alcoholic Fatty Liver Disease: Causal Association or Epiphenomenon?

Article Type: Review

Keywords: nonalcoholic fatty liver disease; NAFLD; diabetes risk; type 2 diabetes; epidemiology.

Corresponding Author: Prof Giovanni Targher,

Corresponding Author's Institution:

First Author: Giovanni Targher

Order of Authors: Giovanni Targher; G. Marchesini

Manuscript Region of Origin: ITALY

Abstract: Nonalcoholic fatty liver disease (NAFLD) has become the leading cause of chronic liver diseases worldwide, causing considerable liverrelated mortality and morbidity. Over the last 10 years, it has also become increasingly evident that NAFLD is a multisystem disease, affecting many extra-hepatic organ systems and interacting with the regulation of multiple metabolic pathways. NAFLD is potentially involved in the aetiology and pathogenesis of type 2 diabetes via its direct contribution to hepatic/peripheral insulin resistance and the systemic release of multiple hepatokines that may adversely affect glucose metabolism and insulin action and secretion. In this updated review, we discuss the rapidly expanding body of clinical and epidemiological evidence that supports a strong link between NAFLD and the risk of developing type 2 diabetes. We also briefly examine the conventional and the more innovative pharmacological approaches for the treatment of NAFLD that may influence the risk of developing type 2 diabetes.

Suggested Reviewers:

Opposed Reviewers: 


\title{
Risk of Type 2 Diabetes in Patients with Non-Alcoholic Fatty Liver Disease: Causal Association or Epiphenomenon?
}

\author{
G. Targher, ${ }^{1}$, G. Marchesini, ${ }^{2}$, C.D. Byrne, ${ }^{3,4}$
}

${ }^{1}$ Division of Endocrinology, Diabetes and Metabolism, Department of Medicine, University and Azienda Ospedaliera Universitaria Integrata of Verona, Verona, Italy

${ }^{2}$ Unit of Metabolic Diseases and Clinical Dietetics, "Alma Mater Studiorum" University, Bologna, Italy

${ }^{3}$ Nutrition and Metabolism, Faculty of Medicine, University of Southampton, Southampton, UK

${ }^{4}$ Southampton National Institute for Health Research Biomedical Research Centre, University Hospital Southampton, UK

Short title: NAFLD and diabetes risk

Word count: abstract $=148$; text $=5,253$ words (excluding title page, references, tables and figure legend); Tables: 2, Figures: 2; Supplemental data: None

\section{Corresponding author:}

Prof. Giovanni Targher, M.D.

Section of Endocrinology, Diabetes and Metabolism

Department of Medicine

University and Azienda Ospedaliera Universitaria Integrata

Piazzale Stefani, 1

37126 Verona, Italy

E-mail: giovanni.targher@univr.it 


\begin{abstract}
Nonalcoholic fatty liver disease (NAFLD) has become the leading cause of chronic liver diseases worldwide, causing considerable liver-related mortality and morbidity. Over the last 10 years, it has also become increasingly evident that NAFLD is a multisystem disease, affecting many extra-hepatic organ systems and interacting with the regulation of multiple metabolic pathways. NAFLD is potentially involved in the aetiology and pathogenesis of type 2 diabetes via its direct contribution to hepatic/peripheral insulin resistance and the systemic release of multiple hepatokines that may adversely affect glucose metabolism and insulin action and secretion. In this updated review, we discuss the rapidly expanding body of clinical and epidemiological evidence that supports a strong link between NAFLD and the risk of developing type 2 diabetes. We also briefly examine the conventional and the more innovative pharmacological approaches for the treatment of NAFLD that may influence the risk of developing type 2 diabetes.
\end{abstract}

Keywords: nonalcoholic fatty liver disease; NAFLD; diabetes risk; type 2 diabetes; epidemiology. 


\section{Introduction}

Nonalcoholic fatty liver disease (NAFLD) encompasses a spectrum of liver pathology including simple steatosis, non-alcoholic steatohepatitis (NASH) with varying amounts of fibrosis and cirrhosis [1]. NAFLD has emerged as a public health problem of epidemic proportions in many parts of the world (affecting up to $30 \%$ of the adult population in the United States and Europe) [1,2]. The prevalence of NAFLD is much higher in patients with type 2 diabetes (ranging from approximately 50\% to 75\%). Notably, patients with type 2 diabetes and NAFLD are also more likely to develop the more severe forms of NAFLD, such as NASH, advanced fibrosis, cirrhosis, and in some cases hepatocellular carcinoma $[1,2]$.

Over the past decade, it has become increasingly clear that NAFLD is not only associated with an increased risk of liver-related morbidity or mortality, but also it is a multisystem disease that affects a variety of extra-hepatic organ systems, and interacts with the regulation of multiple metabolic pathways [3]. Strong evidence indicates that cardiovascular disease is the leading cause of mortality in patients with NAFLD [3,4]. As detailed below, there is now also convincing evidence suggesting that NAFLD may often precede the development of type 2 diabetes. This supports the assertion that the conventional paradigm of NAFLD representing the simple "hepatic manifestation" of the metabolic syndrome is outdated, and that NAFLD might be regarded as an early predictor and determinant for the development of diabetes and other clinical traits of the metabolic syndrome [5]. This finding may have potentially relevant clinical implications for the diagnosis, prevention and treatment of type 2 diabetes.

Specifically, in this narrative review we discuss the rapidly expanding body of clinical evidence that supports a strong association between NAFLD and the risk of new-onset type 2 diabetes, and the putative biological mechanisms underlying this association. We also briefly discuss some of the treatment options for NAFLD that may influence the risk of diabetes.

To this end, although this is not a formal systematic review, we extensively searched PubMed database to identify relevant articles published up to January 2016, using the keywords "non-alcoholic fatty liver disease" or "fatty liver" combined with "incident type 2 diabetes" or "diabetes risk".

\section{Epidemiological evidence linking NAFLD to the risk of new-onset type 2 diabetes}

In this review, we have not discussed the large number of prospective, population-based studies that used serum levels of liver enzymes (or other surrogate markers of NAFLD such as the fatty liver index) to diagnose NAFLD. These studies have consistently shown that mildly elevated serum liver enzymes (mainly serum gamma-glutamyltransferase) are independent, long-term predictors of new-onset type 2 diabetes in various ethnic populations (Asian, American and European people) [6-8].

Data from observational cohort (prospective or retrospective) or case-control studies that used non-invasive imaging techniques (predominantly ultrasonography that has high sensitivity and specificity for detecting moderate and severe steatosis) to diagnose NAFLD are summarized in Table 1. There are now about 20 observational studies that have assessed the association between NAFLD and the risk of new-onset type 2 diabetes [9-25]. The main characteristics of the study populations, the length of follow-up period, the 
diagnostic criteria for diabetes, the relative risks of developing diabetes and the covariates have shown that NAFLD was associated with a substantially increased risk of new-onset type 2 diabetes. The risk of diabetes among these published studies varied markedly from a 33\% increase [14] to a 5.5 fold increase in risk [11]. This wide inter-study variation in risk might reflect differences in NAFLD severity, since the study by Park et al. [15] showed that the 5-year incidence rate of type 2 diabetes increased progressively according to the ultrasonographic severity of NAFLD at baseline (normal: $7.0 \%$, mild: $9.8 \%$, moderate-to-severe: $17.8 \%$ ) in a cohort of 25,232 South Korean nondiabetic middle-aged men. Even after adjusting for multiple confounding variables, the hazard ratios (HRs) for diabetes development were higher in the mild-NAFLD group (adjusted-HR 1.09; 95\% confidence interval [CI] 0.81-1.48) and in the moderate-to-severe-NAFLD group (adjusted-HR 1.73; 95\% CI 1.00-3.01) compared with the no-NAFLD group, respectively. In addition, this wide inter-study variability in NAFLD-associated risk of type 2 diabetes might also reflect differences in the demographic characteristics of the study populations, in the length of follow-up (ranging from a mean period of 3 years to 12.8 years) and in the varying degree of confounder adjustment in individual studies (Table 1).

Using data from an occupational cohort study of over 12,000 South Korean individuals with measurements of insulin resistance (by homeostasis model assessment [HOMA-IR]), overweight/obesity and NAFLD (as detected by ultrasonography) at baseline, Sung et al. [16] have compared the effect of these three risk factors (singly or in combination) on the risk of new-onset diabetes at 5-year follow-up. These data showed that each of these three risk factors was associated with an approximate doubling of the diabetes risk even after adjustment for other established risk factors (for example, with an adjusted odds ratio [OR] of 2.42, 95\% CI 1.74-3.36, for NAFLD). When all three risk factors occurred together in the same individual (and this occurred in approximately $50 \%$ of patients with incident diabetes at follow-up), there was an approximately 14-fold increase in diabetes risk after adjusting for potential confounding variables [16].

Notably, and most interestingly, in the same observational cohort of Korean individuals, the authors have further assessed the risk of new-onset type 2 diabetes at 5 years of follow-up in the following three subgroups: 1) in subjects in whom there was resolution of fatty liver over 5 years, i.e., fatty liver that had been present at baseline was not present at follow-up examination; 2) in subjects in whom there was a development of new fatty liver between baseline and the follow-up examinations; and 3) in subjects in whom there was an increase in severity of fatty liver status, from mild fatty liver noted at baseline to moderate-severe fatty liver, identified at follow-up examination [20]. Interestingly, these data showed that changing fatty liver status over a 5-year period was associated with markedly different risks of incident type 2 diabetes. In particular, as also shown in Fig. 1, there was a significant diabetes risk reduction in those subjects in whom fatty liver on ultrasonography resolved over time. In particular, in those subjects, risk of incident diabetes decreased to the background risk of someone, who had never had fatty liver. Conversely, the subjects in whom the severity of fatty liver worsened over 5 years (from mild to moderate-severe) showed a marked increase in risk of incident diabetes compared with the risk in people with resolution of fatty liver, supporting the notion that more severe forms of NAFLD are associated with higher risk of incident diabetes [20]. Similarly, Yamazaki et al. [21] recently assessed the relationship between improvement of NAFLD and risk of incident type 2 diabetes in a retrospective cohort of 4,604 nondiabetic Japanese individuals followed-up for a period of 10 years. They found that NAFLD at baseline was 
associated with an approximately 2.5 -fold increased risk of incident diabetes, and that NAFLD improvement was significantly associated with a $70 \%$ risk reduction of developing diabetes over time, even after adjusting for age, sex, family history of diabetes, BMI, impaired fasting glycaemia, dyslipidemia, hypertension, and physical exercise [21]. However, these two latter studies are not intervention trials that focused on treating NAFLD; so caution is needed in interpreting these results.

To date, there are very few studies examining the association between histology-diagnosed NAFLD and the risk of incident diabetes. In a cohort study of 129 Sweden adults with biopsy-proven NAFLD and elevated serum liver enzymes, who were followed for approximately 14 years, Ekstedt et al. [26] found that the prevalence of previously known diabetes was $8.5 \%$ at baseline. Notably, at the end of the follow-up, approximately $80 \%$ of these patients developed either new-onset type 2 diabetes or impaired glucose tolerance. Again, patients with NASH had an approximately threefold higher risk of developing diabetes than those with simple steatosis over the follow-up period [26].

Collectively, although there is now convincing evidence that NAFLD is associated with an increased risk of new-onset type 2 diabetes [10-25], and there is emerging evidence that this risk varies according to the severity of NAFLD (as detected either by ultrasonography or by use of non-invasive fibrosis scoring systems) [9,12-14], further evidence is unquestionably needed in non-Asian populations, as nearly all of the studies summarised in Table 1 have been conducted in various Asian populations, and most of the evidence obtained to date has been obtained in South Korean individuals. However, a recent analysis from the Multi-Ethnic Study of Atherosclerosis study involving more than 3,000 United States nondiabetic individuals has confirmed that NAFLD as detected by computed tomography was independently associated with a two-fold increased risk of developing type 2 diabetes [25]. In addition, as also reported above, several population-based cohort studies, involving European and American middle-aged nondiabetic individuals, have repeatedly shown that moderately elevated serum liver enzymes (a proxy of NAFLD) are strongly and independently associated with an increased risk of new-onset type 2 diabetes [6-8].

Another important caveat to keep in mind when examining the results from published studies is that the adjustment for established risk factors of diabetes and other potential confounding factors was often incomplete. For example, data on waist circumference was often lacking, whereas family history of diabetes, insulin resistance index values and physical activity were not always included in multivariate regression models. Additional follow-up studies with a larger panel of established and emerging diabetes risk factors (e.g., higher serum ferritin and lower adiponectin levels that have been also associated with the presence and severity of NAFLD) are needed to firmly establish an independent contribution of NAFLD per se to the risk of new-onset type 2 diabetes. Finally, it is important to underline that in none of the published studies, except for the studies by Shibata et al. [11] and by Ming et al. [23], the diagnosis of diabetes was based on 2-hour post-load plasma glucose concentrations.

\section{Putative biological mechanisms by which NAFLD contributes to diabetes development}

When imbalance occurs between energy intake and energy expenditure, or when there is an intrinsic problem with storing excess energy as triacylglycerol in adipose tissue depots, lipid accumulates in other organs throughout the body. If lipid accumulates in tissues or organs not designed to accumulate fat, e.g., liver or omentum, the term 
'ectopic fat accumulation' infers that lipid accumulation has occurred in a non physiological site with the potential for increasing risk of certain common diseases such as diabetes, CVD and NAFLD [27].

NAFLD is an example of ectopic fat accumulation in liver and this lipid accumulation is usually associated with insulin resistance, abnormal substrate fluxes [28], increased secretion of hepatokines [29], increased gluconeogenesis, decreased glycogen synthesis and inhibition of insulin signalling pathways [30,31]. When excess hepatic lipid accumulates (NAFLD), it not only has the potential for causing insulin resistance but there is also the potential for chronic liver inflammation, increasing risk of progressive fibrotic liver disease, cirrhosis and hepatocellular carcinoma. Such a pathological state also has the potential for increasing both very low-density lipoprotein (VLDL) secretion and hepatic glucose output. Marked liver fat accumulation, increased VLDLs, increased hepatic glucose output and insulin resistance are all associated with increased risk of diabetes. Fig. 2 illustrates the potential mechanisms leading to altered lipid and glucose metabolism resulting from and contributing to insulin resistance and increased hepatic glucose production in NAFLD. The figure schematically illustrates some of the key mechanisms relevant to the pathways that operate in the adipose tissue (panel A), the liver (panel B), and the intestine (panel C).

It is now clear that adipose tissue dysfunction/inflammation is also important in NAFLD pathogenesis, and increasing evidence now suggests that the intestine is also involved in the developing disease process. Alteration of the normal intestinal microbiota (dysbiosis) also plays a key role in regulating several intra-hepatic metabolic and inflammatory pathways that are involved in the development of NAFLD and diabetes. For example, data obtained in mice illustrate the importance of the gut microbiota for affecting hepatic lipid levels, and serum glucose and insulin concentrations. Such data has shown that oral treatment of lean germ-free mice with the caecal microbiota from obese mice caused an increase in hepatic triglyceride accumulation, and insulin resistance with increased serum insulin and glucose concentrations [32]. Several different mechanisms have been suggested that are involved in the pathogenesis of dysbiosis-induced NAFLD and that contribute to the development and progression of liver disease in NAFLD. For example, increased intestinal absorption of multiple bacterial products, such as short-chain fatty acids (e.g., butyrate, propionate and acetate), lipopolysaccharide and endotoxins, have the potential to influence both hepatic glucose and lipid metabolism, promote hepatic inflammation and increase gut permeability, thus adversely influencing the risk of inflammation beyond the liver [27,33,34]. Intestinal dysbiosis perturbs biliary cholesterol metabolism, and altered bile acids in the intestine can modify the gut microbiota. Bile acids are derived initially from hepatic cholesterol metabolism and are capable of acting as signalling molecules which are capable of activating some receptors, e.g. farnesoid X receptor (FXR), and modifying signalling pathways that influence both liver lipid metabolism and hepatic glucose metabolism. Recently, there has been considerable interest in this field, with the appreciated that subtle changes in the bile acid structure can profoundly influence their efficacy as signalling molecules. For adding an ethyl group at carbon position 6 in chenodeoxycholic acid, it markedly affects the ligandbinding capability of chenodeoxycholic acid to the nuclear hormone FXR. Treatment with obeticholic acid has recently shown promise in treating NASH in the Farnesoid X Receptor Ligand Obeticholic Acid in NASH Treatment (FLINT) trial with improvement in liver histology in approximately $50 \%$ of patients with non-cirrhotic NASH [35]. 


\subsection{Hepatic lipid accumulation, insulin resistance, insulin clearance adipose tissue lipolysis} and hepatic glucose production

Although obesity is strongly associated with hepatic steatosis, excess body fat accumulation is not necessarily a requirement for developing NAFLD. People with lipodystrophy have marked insulin resistance and commonly develop hepatic steatosis and type 2 diabetes, strongly suggesting that it is not body fat quantity per se that is important, but it is abnormal adipose tissue function that is a key contributor to NAFLD pathogenesis [36]. In insulin sensitive individuals, post-prandial increases in insulin concentrations are very effective in suppressing lipase activity in adipose tissue to decrease serum free fatty acid (FFA) concentrations and thereby decreased FFA fluxes to the liver. In contrast, in insulin resistant individuals there is decreased inhibition of insulin-mediated suppression of FFA concentrations with resultant increased FFA fluxes to the liver. Specifically, with insulin resistance, increased FFA fluxes to the liver increase the availability of long-chain fatty acyl-CoAs for hepatic lipid metabolism. Such an effect occurs in sedentary obese individuals, who do not benefit from the ameliorating effect of increased muscle activity and increased mitochondrial fatty acid oxidation, which would normally buffer the liver from the burden of high FFA levels [33]. With the increased fluxes of long chain fatty acyl CoAs through the liver, evidence is accumulating that hepatic lipid accumulation is capable of promoting hepatic insulin resistance and hepatic inflammation through accumulation of di-acyl glycerols (DAGs) and protein kinase $\mathrm{C} \varepsilon(\mathrm{PKC}-\varepsilon)$ activity, inhibiting the insulin signalling pathway and promoting insulin resistance (reviewed in detail in [28]). The conversion from TAG to DAG is mediated by adipose triglyceride lipase (ATGL) and comparative Gene Identification-58 (CGI-58) is an activator of ATGL. DAG activates PKC $\varepsilon$ membrane translocation to inhibit the insulin receptor kinase and decrease insulin signalling [37].

With decreased effective insulin signalling activity in subjects with insulin resistance, there is also decreased post-prandial glycogen synthesis. Increased fluxes of hepatic long-chain fatty acyl-CoAs also promote hepatic glucose production, thereby increasing the risk of glucose intolerance and diabetes. Increased fluxes of long-chain fatty acyl-CoAs effects allosteric activation of pyruvate carboxylasephosphoenolpyruvate carboxykinase activity with resulting stimulation of hepatic gluconeogenesis and increased hepatic glucose output. Additionally, increased adipose tissue triacylglycerol lipolysis also produces increased levels of glycerol from the hydrolysis of more triacylglycerol molecules. Once liberated from triacylglycerol, glycerol is not re-esterified back into triacylglycerol by the adipocyte, because the adipocyte does not possess the required glycerol kinase activity. Consequently, increased triacylglycerol hydrolysis results in increased glycerol fluxes to the liver, increasing the production of dihydroacetone phosphate, hepatic gluconeogenesis and the production of hepatic glucose [28].

Hepatic lipid synthesis stimulated by increased fluxes of long-chain acyl Co-As to the liver, increases production of other lipid intermediates, besides DAGs, such, dipalmitoyl phosphatic acid and other lipid products, such as ceramides [38]. Many of these lipid intermediates promote hepatic inflammation [39-42] and increasing risk of progressive liver disease that occurs with NASH. Hepatic lipids that are not esterified also induce endoplasmic reticulum stress, leading to the activation of c-Jun N-terminal kinases and nuclear factor kappa $(\mathrm{NF}-\kappa \mathrm{B})$-light-chain-enhancer of activated $\mathrm{B}$ cells [43], which are two major regulators of inflammatory pathways that also inhibit 
phosphorylation of insulin receptor substrate (IRS)-1 [44], potentially further aggravating hepatic insulin resistance and increasing intra-hepatic cytokine production.

In the liver, ceramides utilise long-chain FAs [45] and ceramides can accumulate into the cells via three main routes: the hydrolysis of the membrane phospholipid sphingomyelin, which is coordinated by the enzyme sphingomyelinase; de novo synthesis from long-chain FAs such as palmitate and serine; and a 'salvage' pathway that utilises sphingosine and forms ceramide $[46,47]$. Although in the past, it was thought that ceramide was simply a structural molecule, there is some evidence that increases in membrane ceramide may cause insulin resistance [48], potentially providing a mechanism to link hepatic lipid metabolism and hepatic inflammation. Recently, it has been suggested that differences in ceramide metabolism may also explain why NAFLD with insulin resistance is associated with features of the metabolic syndrome; whereas the patatin-like phospholipase domain-containing protein 3 (PNPLA3 148MM) genotype associated with NAFLD, is not associated with metabolic syndrome (and thereby with no increased risk of type 2 diabetes) [49]. In such study, the liver lipidome was analysed from tissue obtained from liver biopsies in 125 subjects who were divided into similarly sized groups based on median HOMA-IR ('high $v s$. low HOMA-IR', $\mathrm{n}=62$ and $\mathrm{n}=63$ ) or PNPLA3 genotype (PNPLA3 148MM/MI, $\mathrm{n}=61 \mathrm{vs}$. PNPLA3 148II, $\mathrm{n}=64)$. The results of this study showed that for the 'high HOMA-IR' vs. 'low HOMA-IR' group comparison, in the more insulin resistant group (the high HOMA-IR group) the liver was markedly enriched with saturated and monounsaturated triacylglycerols and free fatty acids, dihydroceramides (markers of de novo ceramide synthesis) and ceramides [49]. Clearly, the results of this study suggest that further work is needed to better understand hepatic processing and re-modelling of liver lipids such as ceramides, and how ceramides cause hepatic insulin resistance in people with genotypes such as PNPLA3 148MM that is known to influence liver disease in NAFLD.

Besides increased insulin resistance in NAFLD, it is also plausible that part of the reason for patients with type 2 diabetes and NAFLD often require large doses of exogenous insulin to help control plasma glucose concentrations, is that insulin clearance may also be increased in patients with NAFLD. Recent data suggest that increased insulin clearance may occur in simple steatosis and also in NASH [50]. These investigators studied hyperinsulinemia and its relationship to liver histology in control subjects, patients with simple steatosis and in patients with NASH. Patients with simple steatosis and NASH had a similar $\sim 30 \%$ reduction in hepatic insulin clearance, when compared to patients without NAFLD. Reduced hepatic insulin clearance was not associated with severity of inflammation, ballooning, and fibrosis. In contrast to hepatic insulin clearance, worse histological inflammation and ballooning (but not steatosis or fibrosis) were associated with a progressive reduction in whole-body insulin clearance [50].

\subsection{Secreted hepatokines, and the role of incretins and glucagon in liver disease and impaired glucose metabolism}

Recently, it has been proposed that there are molecules secreted from the liver that are capable of adversely influencing glucose metabolism in NAFLD. These factors (or hepatokines) include fetuin A [51], adropin [52], angiopoietin-like protein [53], fibroblast growth factor-21 [54], and selenoprotein [55]. All of these hepatokines have been suggested as potential endocrine mediators of insulin resistance and/or glucose intolerance in NAFLD. As such, it has been proposed that these molecules have the potential to adversely influence glucose tolerance in patients with NAFLD. 
Recent interest has also focussed on fetuin-B as a hepatokine that is capable of having an endocrine function beyond the liver to influence adversely insulin sensitivity and cause glucose tolerance. A recent study of 168 hepatokines, of which 32 were differentially secreted in steatotic versus non-steatotic hepatocytes showed that fetuin B was increased in humans with liver steatosis and in patients with type 2 diabetes [56]. These investigators then showed both in in-vitro experiments and in mice that fetuin B impaired insulin action ex vivo in myotubes and in hepatocytes, and also caused glucose intolerance in-vivo in mice. As proof of concept that fetuin B was responsible for glucose intolerance in vivo, they then showed that silencing of fetuin B in the obese mice improved glucose tolerance in these animals [56]. Thus, these data strongly suggest that steatotic and inflamed liver is able to secrete a hepatokine that is capable of having an endocrine function beyond the liver to influence adversely glucose tolerance. It is plausible that the protein secretory profile of hepatocytes in NAFLD is altered with developing steatosis, and the production of hepatokines is linked to inflammation and insulin resistance in NAFLD.

The regulation of glucagon secretion involves the gut hormone glucagon-like peptide-1 (GLP-1) and in type 2 diabetes, fasting hyperglucagonaemia may contribute to increased hepatic glucose production [57]. Although the precise role of glucagon in NAFLD remains uncertain, NAFLD is frequently associated with abnormal glucose tolerance and there has been recently considerable interest in the role of incretins, such as GLP-1, in NAFLD. Liraglutide is one such GLP-1 agonist that is used as a once daily treatment for hyperglycaemia in type 2 diabetes. Although there is not good evidence of GLP-1 receptor expression in the human liver, the safety and efficacy of liraglutide at a dose of $1.8 \mathrm{mg} / \mathrm{day}$ was recently tested in a small randomised clinical trial in patients with biopsy-confirmed NASH [58], as specified in the section below.

\section{Treatment options for NAFLD that may influence risk of type 2 diabetes}

The past decade has been characterized by an intensive search of effective treatments for NAFLD, fostered by the evidence of a significant burden of disease for all national healthcare systems. Behavioural changes, including dietary restriction and increased physical activity, and drug therapy are the pillars of NAFLD treatment. The assessment of their effects on the risk of disease progression has been limited by several factors: 1) the lack of valid surrogate markers, making liver biopsy mandatory to demonstrate solid improvements; 2) treatment outcomes undefined at regulatory levels. Only recently the outcome of NASH improvement or regression, without worsening of fibrosis, had gained general consensus [59]; and 3) limited treatment duration (maximum, 2 years).

Nonetheless, a significant benefit of both weight loss and drug treatment on liver histology has been reported in recent reviews [60,61], but only a few data are available on the risk of progression to diabetes.

\subsection{Weight loss and decreased diabetes risk in NAFLD}

Considering that overweight/obesity and insulin resistance are a hallmark of NAFLD, there is no surprise that weight loss may considerably affect diabetes risk. In most cases, the methodology used for promoting weight loss was the same or was strictly derived from the classical methodology used in the Diabetes Prevention Program [62], where a 58\% reduced risk of diabetes was measured in subjects with prediabetes in a 4-year follow-up [63]. In the same study, there was a consistent decline of serum ALT levels in relation to weight loss in the entire cohort, and weight loss was significantly associated with a decreased risk of abnormal liver enzymes in subjects with normal ALT levels at baseline [64]. No data were 
reported on progression to diabetes in relation to serum ALT changes, and circulating ALT levels remain a very crude marker of NAFLD and NAFLD progression. In 1,087 subjects with ultrasonography-detected NAFLD, randomly assigned to a lifestyle modification intervention based on physical activity, diet and behaviour therapy were compared with usual care on NAFLD remission [65]. Weight loss was larger in the intervention group and was associated with a significant reduction of serum liver enzymes, as well as a 30-mg/dL reduction in blood glucose. No data were reported on incident diabetes. Unfortunately, trials of dietary or behavioural treatment of NAFLD rarely classify their population in terms of glucose regulation as normal, pre-diabetes or diabetes, to verify the effectiveness of this treatment on diabetes risk, and the short duration of intervention precludes any analysis. Vilar-Gomez et al. recently reported the result of an intensive, prospective behavioural intervention aimed at weight loss in a 1-year follow-up of 293 NASH patients, observed at a tertiary medical center in Havana, Cuba [66]. The outcome measure was NASH resolution without worsening of fibrosis in paired liver biopsies (available in 261 participants). Weight loss $\geq 5 \%$ was observed in $30 \%$ and the probability to achieve NASH resolution was strictly dependent on the amount of weight loss $(58 \%$ in subjects with weight loss $\geq 5 \%$; $90 \%$ with weight loss $\geq 10 \%$ ). Only $33 \%$ of cases had type 2 diabetes, with another $33 \%$ with pre-diabetes and 33\% with normal glucose regulation [66]. Follow-up glucose data have not been reported, but it will be largely impossible to demonstrate if the expected reduction of incident diabetes is due to NASH resolution or to weight loss per se.

Many more data are available on diabetes risk in relation to bariatric surgery-induced weight loss. In the Swedish Obese Subjects intervention study, surgery produced a systematic reduction of incident diabetes $v s$. obese matched controls [67]; the effect was directly associated with the amount of weight loss [68], not with baseline BMI [69]. In the same cohort of morbidly obese subjects undergoing surgery, weight loss was accompanied by a systematic reduction of serum liver enzymes at 2-year and 10-year follow-up, considered surrogate markers of steatosis, also proportional to the degree of weight loss [70]. In a recent study, follow-up biopsies in morbidly obese patients with NASH at baseline have shown that the massive weight loss induced by bariatric surgery was accompanied by NASH resolution in $85 \%$ of cases, and a $10-\mathrm{mg} / \mathrm{dL}$ reduction of blood glucose. Notably, those patients who did not achieve NASH resolution were characterized by lower weight loss and maintained higher values of insulin resistance [71]. In conclusion, a large body of evidence suggests to date that weight loss, independently of the therapeutic strategy, significantly improves NAFLD and NASH and reduces the risk of incident diabetes, but the independent effect of improved liver disease has never been demonstrated.

\subsection{Drug treatment of NAFLD with a defined impact on glucose metabolism}

Considering that insulin resistance is the hallmark of NAFLD, drugs acting on glucose metabolism have long been considered for NAFLD treatment [35,58,72-80]. Insulin sensitizers have been tested in several clinical trials of different duration. They are very likely to reduce both the risk of incident diabetes and to improve metabolic control in the NAFLD population without and with diabetes, respectively. This therapeutic effect has been demonstrated with metformin, which is the basis of diabetes treatment and significantly reduces the progression of pre-diabetes to diabetes in several large intervention trials. However, initial evidence for an effect of metformin on NAFLD histology was not confirmed $[72,76,77,80]$, and the effects of metformin on liver disease progression have been questioned [81].

Many more data are available with the peroxisome-proliferator activator receptor- $\gamma$ (PPAR- $\gamma$ ) agonists (glitazones) as insulin sensitizers. They definitely reduce progression to 
diabetes in persons at risk, via enhanced insulin sensitivity in skeletal muscles and in the liver as well as in the adipose tissue, where they also promote adipocyte differentiation. The first evidence with glitazones on NAFLD was produced in 2001, a small pilot trial reported reduced serum ALT levels in 10 patients treated with troglitazone, but minor or no effects on liver histology [82]. Nine cases were free of diabetes, and troglitazone was highly effective in reducing progression from prediabetes to diabetes in a treatment arm inside the Diabetes Prevention Program [83]. Troglitazone was later withdrawn from the market, but both rosiglitazone and pioglitazone treatment in the early prediabetes phase have shown a beneficial effect on diabetes risk prevention [84], and are the most extensive studied drugs on NASH treatment [73-75,78,79]. Also acarbose treatment reduces the risk of diabetes development [85], but no data have been raised on histologic outcomes of NAFLD and no effects have been demonstrated on hepatic biochemistry.

Other drugs have more recently entered the arena. The dual PPAR- $\alpha / \delta$ agonist GFT-505 (Elafibranor ${ }^{\circledR}$ ) showed potentially useful results in a small pilot study in obesity, where it also demonstrated an insulin-sensitizing activity [86]. GFT-505 has recently completed a phase IIb trial with positive results on NAFLD histology, and the publication of final results is eagerly awaited. Bile acids have been reported to regulate hepatic lipid and glucose metabolism through FXR, a member of the nuclear hormone receptor superfamily, and TGR5, a G protein-coupled bile acid receptor 1. Whereas no solid data are available for a beneficial effect of ursodeoxycholic acid on histology in NASH patients, obeticholic acid has recently been reported to promote NASH remission in a phase II study [35]. However, no advantage on glucose metabolism was reported and the use of this compound may be limited by some important side effects (e.g., pruritus and increase in LDL-cholesterol concentrations).

The most interesting drugs for a potentially favourable effect on both glucose and liver disease is the class of incretin mimetics. The rationale for their use [both the glucagon-like peptide-1 receptor agonists (GLP-1Ra) and the dipeptidyl peptidase-4 inhibitors (DPP-4i)] in NAFLD comes from a report of a reduced expression of GLP-1 receptors in the biopsies from NASH patients, in comparison with control biopsies [87]. GLP-1Ra and DPP-4i are also likely to improve NAFLD through improved insulin sensitivity [88]. Initial studies in NASH were carried out with the short-acting GLP-1Ra exenatide; in a pilot study it produced a positive effect on liver histopathology in three out of 8 cases [89]. The long-acting GLP-1Ra liraglutide has now completed a phase IIb trial, showing a significant positive effect on NASH remission, independent of the presence of diabetes [58]. The mechanism(s) might be mediated by improved insulin sensitivity and reduced hepatic de novo lipogenesis [90]. At present, several phase II studies are being planned to measure the long-term effects of different GLP-1Ra in NAFLD, having the strictly defined histological outcome of NASH remission as primary outcome. Future studies should also compare the relative effects of GLP-1Ra treatment in comparison to weight loss programs in obese subjects, whereas drug treatment will remain the treatment of choice in lean NAFLD [91].

\section{Conclusions}

In this updated review of the published studies, we provide further support to the strong association between NAFLD and increased risk of new-onset type 2 diabetes, though causality remains to be proven in well-controlled prospective and intervention studies. Future studies are also needed to assess the potential added value of using the presence of NAFLD to predict the risk of incident type 2 diabetes beyond that provided by common risk factors for diabetes. Finally, in the presence of NAFLD therapeutic strategies should tackle both the risk of advanced liver disease and the risk of type 2 diabetes, in turn responsible for liver disease progression. 
Author Contributions: GT conceived and designed the study. GT, GM and CDB researched data and wrote the manuscript.

Conflicts of interest: none.

Acknowledgments: GT is supported in part by grants from the University School of Medicine of Verona, Verona, Italy. CDB is supported in part by the Southampton National Institute for Health Research Biomedical Research Centre

\section{References}

[1] Rinella ME. Nonalcoholic fatty liver disease: a systematic review. JAMA. 2015;313:2263-73.

[2] Non-alcoholic Fatty Liver Disease Study Group, Lonardo A, Bellentani S, Argo CK, Ballestri S, Byrne CD, et al. Epidemiological modifiers of non-alcoholic fatty liver disease: Focus on high-risk groups. Dig Liver Dis. 2015;47:997-1006.

[3] Byrne CD, Targher G. NAFLD: a multisystem disease. J Hepatol. 2015;62:S47-64.

[4] Targher G, Day CP, Bonora E. Risk of cardiovascular disease in patients with nonalcoholic fatty liver disease. N Engl J Med. 2010;363:1341-50.

[5] Lonardo A, Ballestri S, Marchesini G, Angulo P, Loria P. Nonalcoholic fatty liver disease: a precursor of the metabolic syndrome. Dig Liver Dis. 2015;47:181-90.

[6] Fraser A, Harris R, Sattar N, Ebrahim S, Davey Smith G, Lawlor DA. Alanine aminotransferase, gamma-glutamyltransferase, and incident diabetes: the British Women's Heart and Health Study and meta-analysis. Diabetes Care. 2009;32:741-50.

[7] Musso G, Gambino R, Cassader M, Pagano G. Meta-analysis: natural history of nonalcoholic fatty liver disease (NAFLD) and diagnostic accuracy of non-invasive tests for liver disease severity. Ann Med. 2011;43:617-49.

[8] Ballestri S, Zona S, Targher G, Romagnoli D, Baldelli E, Nascimbeni F, et al. Nonalcoholic fatty liver disease is associated with an almost two-fold increased risk of incident type 2 diabetes and metabolic syndrome. Evidence from a systematic review and meta-analysis. J Gastroenterol Hepatol. 2015 Dec 14. doi: 10.1111/jgh.13264 [Epub ahead of print].

[9] Okamoto M, Takeda Y, Yoda Y, Kobayashi K, Fujino MA, Yamagata Z. The association of fatty liver and diabetes risk. J Epidemiol. 2003;13:15-21.

[10] Fan JG, Li F, Cai XB, Peng YD, Ao QH, Gao Y. Effects of nonalcoholic fatty liver disease on the development of metabolic disorders. J Gastroenterol Hepatol. 2007;22:1086-91.

[11] Shibata M, Kihara Y, Taguchi M, Tashiro M, Otsuki M. Nonalcoholic fatty liver disease is a risk factor for type 2 diabetes in middle-aged Japanese men. Diabetes Care. 2007;30:2940-4.

[12] Kim CH, Park JY, Lee KU, Kim JH, Kim HK. Fatty liver is an independent risk factor for the development of Type 2 diabetes in Korean adults. Diabet Med. 2008;25:476-81.

[13] Yamada T, Fukatsu M, Suzuki S, Wada T, Yoshida T, Joh T. Fatty liver predicts impaired fasting glucose and type 2 diabetes mellitus in Japanese undergoing a health checkup. J Gastroenterol Hepatol. 2010;25:352-6. 
[14] Bae JC, Rhee EJ, Lee WY, Park SE, Park CY, Oh KW, et al. Combined effect of nonalcoholic fatty liver disease and impaired fasting glucose on the development of type 2 diabetes: a 4-year retrospective longitudinal study. Diabetes Care. 2011;34:727-9.

[15] Park SK, Seo MH, Shin HC, Ryoo JH. Clinical availability of nonalcoholic fatty liver disease as an early predictor of type 2 diabetes mellitus in Korean men: 5-year prospective cohort study. Hepatology. 2013;57:1378-83.

[16] Sung KC, Jeong WS, Wild SH, Byrne CD. Combined influence of insulin resistance, overweight/obesity, and fatty liver as risk factors for type 2 diabetes. Diabetes Care. 2012;35:717-22.

[17] Kasturiratne A, Weerasinghe S, Dassanayake AS, Rajindrajith S, de Silva AP, Kato $\mathrm{N}$, et al. Influence of non-alcoholic fatty liver disease on the development of diabetes mellitus. J Gastroenterol Hepatol. 2013;28:142-7.

[18] Chang Y, Jung HS, Yun KE, Cho J, Cho YK, Ryu S. Cohort study of non-alcoholic fatty liver disease, NAFLD fibrosis score, and the risk of incident diabetes in a Korean population. Am J Gastroenterol. 2013;108:1861-8.

[19] Choi JH, Rhee EJ, Bae JC, Park SE, Park CY, Cho YK, et al. Increased risk of type 2 diabetes in subjects with both elevated liver enzymes and ultrasonographically diagnosed nonalcoholic fatty liver disease: a 4-year longitudinal study. Arch Med Res. 2013;44:115-20.

[20] Sung KC, Wild SH, Byrne CD. Resolution of fatty liver and risk of incident diabetes. J Clin Endocrinol Metab. 2013;98:3637-43.

[21] Yamazaki H, Tsuboya T, Tsuji K, Dohke M, Maguchi H. Independent association between improvement of nonalcoholic fatty liver disease and reduced incidence of type 2 diabetes. Diabetes Care. 2015;38:1673-9.

[22] Fukuda T, Hamaguchi M, Kojima T, Hashimoto Y, Ohbora A, Kato T, et al. The impact of non-alcoholic fatty liver disease on incident type 2 diabetes mellitus in nonoverweight individuals. Liver Int. 2016;36:275-83.

[23] Ming J, Xu S, Gao B, Liu G, Ji Y, Yang F, et al. Non-alcoholic fatty liver disease predicts type 2 diabetes mellitus, but not prediabetes, in Xi'an, China: a five-year cohort study. Liver Int. 2015;35:2401-7.

[24] Li WD, Fu KF, Li GM, Lian YS, Ren AM, Chen YJ, et al. Comparison of effects of obesity and non-alcoholic fatty liver disease on incidence of type 2 diabetes mellitus. World J Gastroenterol. 2015;21:9607-13.

[25] Shah RV, Allison MA, Lima JA, Bluemke DA, Abbasi SA, Ouyang P, et al. Liver fat, statin use, and incident diabetes: The Multi-Ethnic Study of Atherosclerosis. Atherosclerosis. 2015;242:211-7.

[26] Ekstedt M, Franzen LE, Mathiesen UL, Thorelius L, Holmqvist M, Bodemar G, et al. Long-term follow-up of patients with NAFLD and elevated liver enzymes. Hepatology. 2006;44:865-73.

[27] Byrne CD. Ectopic fat, insulin resistance and non-alcoholic fatty liver disease. Proc Nutr Soc. 2013;72:412-9.

[28] Samuel VT, Shulman GI. The pathogenesis of insulin resistance: integrating signaling pathways and substrate flux. J Clin Invest. 2016;126:12-22.

[29] Kantartzis K, Machann J, Schick F, Fritsche A, Haring HU, Stefan N. The impact of liver fat vs visceral fat in determining categories of prediabetes. Diabetologia. 2010;53:882-9.

[30] Gao Z, Zhang J, Kheterpal I, Kennedy N, Davis RJ, Ye J. Sirtuin 1 (SIRT1) protein degradation in response to persistent c-Jun N-terminal kinase 1 (JNK1) activation contributes to hepatic steatosis in obesity. J Biol Chem. 2011;286:22227-34. 
[31] Samuel VT, Liu ZX, Qu X, Elder BD, Bilz S, Befroy D, et al. Mechanism of hepatic insulin resistance in non-alcoholic fatty liver disease. J Biol Chem. 2004;279:3234553.

[32] Backhed F, Ding H, Wang T, Hooper LV, Koh GY, Nagy A, et al. The gut microbiota as an environmental factor that regulates fat storage. Proc Natl Acad Sci U S A. 2004;101:15718-23.

[33] Byrne CD. Dorothy Hodgkin Lecture 2012: Non-alcoholic fatty liver disease, insulin resistance and ectopic fat: a new problem in diabetes management. Diabet Med. 2012;29:1098-107.

[34] Mehal WZ. The Gordian Knot of dysbiosis, obesity and NAFLD. Nat Rev Gastroenterol Hepatol. 2013;10:637-44.

[35] Neuschwander-Tetri BA, Loomba R, Sanyal AJ, Lavine JE, Van Natta ML, Abdelmalek MF, et al. Farnesoid X nuclear receptor ligand obeticholic acid for noncirrhotic, non-alcoholic steatohepatitis (FLINT): a multicentre, randomised, placebocontrolled trial. Lancet. 2015;385:956-65.

[36] Jornayvaz FR, Shulman GI. Diacylglycerol activation of protein kinase Cepsilon and hepatic insulin resistance. Cell Metab. 2012;15:574-84.

[37] Cantley JL, Yoshimura T, Camporez JP, Zhang D, Jornayvaz FR, Kumashiro N, et al. CGI-58 knockdown sequesters diacylglycerols in lipid droplets/ER-preventing diacylglycerol-mediated hepatic insulin resistance. Proc Natl Acad Sci U S A. 2013;110:1869-74.

[38] Samuel VT, Shulman GI. Mechanisms for insulin resistance: common threads and missing links. Cell. 2012;148:852-71.

[39] Yamaguchi K, Yang L, McCall S, Huang J, Yu XX, Pandey SK, et al. Inhibiting triglyceride synthesis improves hepatic steatosis but exacerbates liver damage and fibrosis in obese mice with nonalcoholic steatohepatitis. Hepatology. 2007;45:136674.

[40] Schenk S, Saberi M, Olefsky JM. Insulin sensitivity: modulation by nutrients and inflammation. J Clin Invest. 2008;118:2992-3002.

[41] Leroux A, Ferrere G, Godie V, Cailleux F, Renoud ML, Gaudin F, et al. Toxic lipids stored by Kupffer cells correlates with their pro-inflammatory phenotype at an early stage of steatohepatitis. J Hepatol. 2012;57:141-9.

[42] Perry RJ, Samuel VT, Petersen KF, Shulman GI. The role of hepatic lipids in hepatic insulin resistance and type 2 diabetes. Nature. 2014;510:84-91.

[43] Hotamisligil GS. Endoplasmic reticulum stress and the inflammatory basis of metabolic disease. Cell. 2010;140:900-17.

[44] Tilg H, Moschen AR. Insulin resistance, inflammation, and non-alcoholic fatty liver disease. Trends Endocrinol Metab. 2008;19:371-9.

[45] Watt MJ, Barnett AC, Bruce CR, Schenk S, Horowitz JF, Hoy AJ. Regulation of plasma ceramide levels with fatty acid oversupply: evidence that the liver detects and secretes de novo synthesised ceramide. Diabetologia. 2012;55:2741-6.

[46] Yang G, Badeanlou L, Bielawski J, Roberts AJ, Hannun YA, Samad F. Central role of ceramide biosynthesis in body weight regulation, energy metabolism, and the metabolic syndrome. Am J Physiol Endocrinol Metab. 2009;297:E211-24.

[47] Kolesnick RN, Kronke M. Regulation of ceramide production and apoptosis. Annu Rev Physiol. 1998;60:643-65.

[48] Lipina C, Hundal HS. Sphingolipids: agents provocateurs in the pathogenesis of insulin resistance. Diabetologia. 2011;54:1596-607.

[49] Luukkonen PK, Zhou Y, Sadevirta S, Leivonen M, Arola J, Oresic M, et al. Ceramides dissociate steatosis and insulin resistance in the human liver in non- 
alcoholic fatty liver disease. J Hepatol. 2016 Jan 11. pii: S0168-8278(16)00005-2. doi: 10.1016/j.jhep.2016.01.002. [Epub ahead of print].

[50] Bril F, Lomonaco R, Orsak B, Ortiz-Lopez C, Webb A, Tio F, et al. Relationship between disease severity, hyperinsulinemia, and impaired insulin clearance in patients with nonalcoholic steatohepatitis. Hepatology. 2014;59:2178-87.

[51] Pal D, Dasgupta S, Kundu R, Maitra S, Das G, Mukhopadhyay S, et al. Fetuin-A acts as an endogenous ligand of TLR4 to promote lipid-induced insulin resistance. Nat Med. 2012;18:1279-85.

[52] Kumar KG, Trevaskis JL, Lam DD, Sutton GM, Koza RA, Chouljenko VN, et al. Identification of adropin as a secreted factor linking dietary macronutrient intake with energy homeostasis and lipid metabolism. Cell Metab. 2008;8:468-81.

[53] Oike Y, Akao M, Kubota Y, Suda T. Angiopoietin-like proteins: potential new targets for metabolic syndrome therapy. Trends Mol Med. 2005;11:473-9.

[54] Kharitonenkov A, Shiyanova TL, Koester A, Ford AM, Micanovic R, Galbreath EJ, et al. FGF-21 as a novel metabolic regulator. J Clin Invest. 2005;115:1627-35.

[55] Misu H, Takamura T, Takayama H, Hayashi H, Matsuzawa-Nagata N, Kurita S, et al. A liver-derived secretory protein, selenoprotein $\mathrm{P}$, causes insulin resistance. Cell Metab. 2010;12:483-95.

[56] Meex RC, Hoy AJ, Morris A, Brown RD, Lo JC, Burke M, et al. Fetuin B Is a Secreted Hepatocyte Factor Linking Steatosis to Impaired Glucose Metabolism. Cell Metab. 2015;22:1078-89.

[57] Baron AD, Schaeffer L, Shragg P, Kolterman OG. Role of hyperglucagonemia in maintenance of increased rates of hepatic glucose output in type II diabetics. Diabetes. 1987;36:274-83.

[58] Armstrong MJ, Gaunt P, Aithal GP, Barton D, Hull D, Parker R, et al. Liraglutide safety and efficacy in patients with non-alcoholic steatohepatitis (LEAN): a multicentre, double-blind, randomised, placebo-controlled phase 2 study. Lancet. 2016;387:679-90.

[59] Ratziu V, Goodman Z, Sanyal A. Current efforts and trends in the treatment of NASH. J Hepatol. 2015;62:S65-S75.

[60] Mazzella N, Ricciardi LM, Mazzotti A, Marchesini G. The role of medications for the management of patients with NAFLD. Clin Liver Dis. 2014;18:73-89.

[61] Marchesini G, Petta S, Dalle Grave R. Diet, weight loss, and liver health in NAFLD: pathophysiology, evidence and practice. Hepatology. 2015; Dec 11. doi: 10.1002/hep.28392 [Epub ahead of print].

[62] The Diabetes Prevention Program Research Group. The Diabetes Prevention Program (DPP): description of lifestyle intervention. Diabetes Care. 2002;25:2165-71.

[63] Knowler WC, Barrett-Connor E, Fowler SE, Hamman RF, Lachin JM, Walker EA, et al. Reduction in the incidence of type 2 diabetes with lifestyle intervention or metformin. N Engl J Med. 2002;346:393-403.

[64] Krakoff J, Clark JM, Crandall JP, Wilson C, Molitch ME, Brancati FL, et al. Effects of metformin and weight loss on serum alanine aminotransferase activity in the Diabetes Prevention Program. Obesity (Silver Spring). 2010;18:1762-7.

[65] Sun WH, Song MQ, Jiang CQ, Xin YN, Ma JL, Liu YX, et al. Lifestyle intervention in non-alcoholic fatty liver disease in Chengyang District, Qingdao, China. World J Hepatol. 2012;4:224-30.

[66] Vilar-Gomez E, Martinez-Perez Y, Calzadilla-Bertot L, Torres-Gonzalez A, GraOramas B, Gonzalez-Fabian L, et al. Weight loss through lifestyle modification significantly reduces features of nonalcoholic steatohepatitis. Gastroenterology. 2015;149:367-78 e5. 
[67] Carlsson LM, Peltonen M, Ahlin S, Anveden A, Bouchard C, Carlsson B, et al. Bariatric surgery and prevention of type 2 diabetes in Swedish obese subjects. N Engl J Med. 2012;367:695-704.

[68] Sjoholm K, Sjostrom E, Carlsson LM, Peltonen M. Weight change-adjusted effects of gastric bypass surgery on glucose metabolism: two- and 10-year results from the Swedish Obese Subjects (SOS) study. Diabetes Care. 2015; Dec 17. pii: dc151407 [Epub ahead of print].

[69] Sjoholm K, Pajunen P, Jacobson P, Karason K, Sjostrom CD, Torgerson J, et al. Incidence and remission of type 2 diabetes in relation to degree of obesity at baseline and 2 year weight change: the Swedish Obese Subjects (SOS) study. Diabetologia. 2015;58:1448-53.

[70] Burza MA, Romeo S, Kotronen A, Svensson PA, Sjoholm K, Torgerson JS, et al. Long-term effect of bariatric surgery on liver enzymes in the Swedish Obese Subjects (SOS) study. PLoS One. 2013;8:e60495.

[71] Lassailly G, Caiazzo R, Buob D, Pigeyre M, Verkindt H, Labreuche J, et al. Bariatric surgery reduces features of nonalcoholic steatohepatitis in morbidly obese patients. Gastroenterology. 2015;149:379-88.

[72] Bugianesi E, Gentilcore E, Manini R, Natale S, Vanni E, Villanova N, et al. A randomized controlled trial of metformin versus vitamin $\mathrm{E}$ or prescriptive diet in nonalcoholic fatty liver disease. Am J Gastroenterol. 2005;100:1082-90.

[73] Belfort R, Harrison SA, Brown K, Darland C, Finch J, Hardies J, et al. A placebocontrolled trial of pioglitazone in subjects with nonalcoholic steatohepatitis. N Engl J Med. 2006;355:2297-307.

[74] Ratziu V, Giral P, Jacqueminet S, Charlotte F, Hartemann-Heurtier A, Serfaty L, et al. Rosiglitazone for nonalcoholic steatohepatitis: one-year results of the randomized placebo-controlled Fatty Liver Improvement with Rosiglitazone Therapy (FLIRT) Trial. Gastroenterology. 2008;135:100-10.

[75] Aithal GP, Thomas JA, Kaye PV, Lawson A, Ryder SD, Spendlove I, et al. Randomized, placebo-controlled trial of pioglitazone in nondiabetic subjects with nonalcoholic steatohepatitis. Gastroenterology. 2008;135:1176-84.

[76] Haukeland JW, Konopski Z, Eggesbo HB, von Volkmann HL, Raschpichler G, Bjoro $\mathrm{K}$, et al. Metformin in patients with non-alcoholic fatty liver disease: a randomized, controlled trial. Scand J Gastroenterol. 2009;44:853-60.

[77] Shields WW, Thompson KE, Grice GA, Harrison SA, Coyle WJ. The effect of metformin and standard therapy versus standard therapy alone in nondiabetic patients with insulin resistance and nonalcoholic steatohepatitis (NASH): a pilot trial. Therap Adv Gastroenterol. 2009;2:157-63.

[78] Ratziu V, Charlotte F, Bernhardt C, Giral P, Halbron M, Lenaour G, et al. Long-term efficacy of rosiglitazone in nonalcoholic steatohepatitis: results of the fatty liver improvement by rosiglitazone therapy (FLIRT 2) extension trial. Hepatology. 2010;51:445-53.

[79] Sanyal AJ, Chalasani N, Kowdley KV, McCullough A, Diehl AM, Bass NM, et al. Pioglitazone, vitamin E, or placebo for nonalcoholic steatohepatitis. N Engl J Med. 2010;362:1675-85.

[80] Lavine JE, Schwimmer JB, Van Natta ML, Molleston JP, Murray KF, Rosenthal P, et al. Effect of vitamin E or metformin for treatment of nonalcoholic fatty liver disease in children and adolescents: the TONIC randomized controlled trial. JAMA. 2011;305:1659-68.

[81] Li Y, Liu L, Wang B, Wang J, Chen D. Metformin in non-alcoholic fatty liver disease: A systematic review and meta-analysis. Biomed Rep. 2013;1:57-64. 
[82] Caldwell SH, Hespenheide EE, Redick JA, Iezzoni JC, Battle EH, Sheppard BL. A pilot study of a thiazolidinedione, troglitazone, in nonalcoholic steatohepatitis. Am J Gastroenterol. 2001;96:519-25.

[83] Knowler WC, Hamman RF, Edelstein SL, Barrett-Connor E, Ehrmann DA, Walker EA, et al. Prevention of type 2 diabetes with troglitazone in the Diabetes Prevention Program. Diabetes. 2005;54:1150-6.

[84] DeFronzo RA, Abdul-Ghani M. Type 2 diabetes can be prevented with early pharmacological intervention. Diabetes Care. 2011;34 Suppl 2:S202-9.

[85] Chiasson JL, Josse RG, Gomis R, Hanefeld M, Karasik A, Laakso M, et al. Acarbose for prevention of type 2 diabetes mellitus: the STOP-NIDDM randomised trial. Lancet. 2002;359:2072-7.

[86] Cariou B, Zair Y, Staels B, Bruckert E. Effects of the new dual PPAR alpha/delta agonist GFT505 on lipid and glucose homeostasis in abdominally obese patients with combined dyslipidemia or impaired glucose metabolism. Diabetes Care.

2011;34:2008-14.

[87] Pedersen J, Holst JJ. Glucagon like-peptide 1 receptor and the liver. Liver Int. 2011;31:1243-5.

[88] Kern M, Kloting N, Niessen HG, Thomas L, Stiller D, Mark M, et al. Linagliptin improves insulin sensitivity and hepatic steatosis in diet-induced obesity. PLoS One. 2012;7:e38744.

[89] Kenny PR, Brady DE, Torres DM, Ragozzino L, Chalasani N, Harrison SA. Exenatide in the treatment of diabetic patients with non-alcoholic steatohepatitis: a case series. Am J Gastroenterol. 2010;105:2707-9.

[90] Armstrong MJ, Hull D, Guo K, Barton D, Hazlehurst JM, Gathercole LL, et al. Glucagon-like peptide 1 decreases lipotoxicity in non-alcoholic steatohepatitis. J Hepatol. 2016;64:399-408.

[91] Gastaldelli A, Marchesini G. Time for glucagon like peptide-1 receptor agonists treatment for patients with NAFLD? J Hepatol. 2016;64:262-4. 


\section{FIGURE LEGENDS}

Fig. 1. Incident type 2 diabetes at 5 -year follow-up according to changes in fatty liver status on ultrasonography between baseline and follow-up in an occupational cohort of 13,218 South Korean nondiabetic individuals. Change in fatty liver status over time was associated with markedly variable risks of incident type 2 diabetes $(\mathrm{P}<0.001$ when compared with the "no steatosis" category). Adapted from Sung et al. [20].

Fig. 2. Potential mechanisms leading to altered lipid and glucose metabolism resulting from and contributing to insulin resistance and increased hepatic glucose production in NAFLD. Panel A: adipose tissue, panel B: liver, and panel C: intestine.

(A)

Adipose tissue. Synthesis of lipid intermediates from long-chain fatty acids (LCFAs), e.g., lyso-phosphatidic acid, phosphatidic acid (PA), di-acylglycerol (DAG) and tri-acylglycerol (TAG). Synthesis of various species of DAG in particular may promote adipose tissue inflammation. Increased production of free fatty acids (FFAs) and glycerol from hydrolysis of TAG may promote hepatic gluconeogenesis and increase hepatic glucose output/production.

(B)

Liver. Synthesis of lipid intermediates from LCFAs, e.g., ceramide, lyso-phosphatidic acid, phosphatidic acid (PA), di-acylglycerol (DAG), tri-acylglycerol (TAG) and very low-density lipoprotein (VLDL) secretion. Synthesis of various species of DAG in particular may promote hepatic inflammation; and DAG and possibly ceramide and di-palmitoylphosphatidic acid (Di-P PA) increase hepatic insulin resistance by decreasing efficient insulin signalling (e.g. via DAG/PKC $\varepsilon$ inhibition of insulin receptor kinase activity) to decrease glycogen synthesis.

(C)

Intestine. Dysbiosis, perhaps caused by alterations in diet and genetic factors, increases synthesis of secondary bile acids with consequent hepatic toll-like receptor-4 (TLR-4) activation, altered farnesoid X receptor (FXR) activity and subsequent increased hepatic inflammation, fibrosis, increased risk of cancer and increased hepatic glucose production. In NAFLD and insulin resistance, dysfunction of glucagon-like peptide (GLP-1) secretion and altered short chain fatty acid (SCFA) production may also adversely influence hepatic gluconeogenesis and lipogenesis. 
Table 1 - Principal observational (retrospective/prospective or case-control) studies of the association between NAFLD and the incidence of type 2 diabetes (ordered by publication year).

\begin{tabular}{|c|c|c|c|c|c|}
\hline $\begin{array}{l}\text { Authors, } \\
\text { Year (ref.) }\end{array}$ & $\begin{array}{l}\text { Study design, Sample size, Population, } \\
\text { Follow-up, and NAFLD Diagnostic tool }\end{array}$ & $\begin{array}{l}\text { Diagnosis of Incident } \\
\text { Diabetes }\end{array}$ & $\begin{array}{l}\text { No. incident cases of } \\
\text { diabetes; \% in non- } \\
\text { NAFLD vs. NAFLD } \\
\text { cases }\end{array}$ & $\begin{array}{l}\text { Adjustments } \\
\text { Considered }\end{array}$ & Main Results \\
\hline $\begin{array}{l}\text { Okamoto et } \\
\text { al. } 2003 \text { [9] }\end{array}$ & $\begin{array}{l}\text { Retrospective cohort study } \\
\mathrm{n}=840 \text { nondiabetic Japanese subjects; } 10 \\
\text { years; liver ultrasonography }\end{array}$ & $\begin{array}{l}\text { Fasting glucose } \geq 7.8 \\
\mathrm{mmol} / \mathrm{l} \text { or } \mathrm{HbA} 1 \mathrm{c} \geq 6.5 \% \\
\text { or drug treatment }\end{array}$ & $\begin{array}{l}\mathrm{n}=82 \text { incident cases } \\
7.6 \% \text { vs. } 22.5 \%\end{array}$ & $\begin{array}{l}\text { Age, sex, BMI, family } \\
\text { history of diabetes, } \\
\text { fasting glucose, HbA1c, } \\
\text { alcohol intake, frequency } \\
\text { of check-ups and } \\
\text { changes of BMI during } \\
\text { follow-up }\end{array}$ & $\begin{array}{l}\text { NAFLD was associated with } \\
\text { incident diabetes in univariate } \\
\text { analysis (OR 2.62, 95\% CI 1.6- } \\
\text { 4.3). This association } \\
\text { disappeared after adjusting for } \\
\text { confounders (aOR } 1.83,95 \% \text { CI } \\
0.9-3.5 \text { ) }\end{array}$ \\
\hline $\begin{array}{l}\text { Fan et al. } \\
2007[10]\end{array}$ & $\begin{array}{l}\text { Nested case-control study } \\
\mathrm{n}=358 \text { Chinese NAFLD patients and } 788 \\
\text { no-NAFLD, matched for age and sex; } 6 \\
\text { years; liver ultrasonography }\end{array}$ & $\begin{array}{l}\text { Fasting glucose } \geq 7.8 \\
\text { mmol/l, clinical history or } \\
\text { drug treatment }\end{array}$ & $\begin{array}{l}\mathrm{n}=102 \text { incident cases } \\
5.2 \% \text { vs. } 20.3 \%\end{array}$ & Age, sex, BMI & $\begin{array}{l}\text { NAFLD was independently } \\
\text { associated with incident diabetes } \\
\text { (aOR 4.63, 95\% CI 3.0-7.1, } \\
\mathrm{P}<0.001)\end{array}$ \\
\hline $\begin{array}{l}\text { Shibata et } \\
\text { al. } 2007 \\
{[11]}\end{array}$ & $\begin{array}{l}\text { Retrospective cohort study with a nested } \\
\text { case-control analysis } n=3,189 \text { male } \\
\text { Japanese workers with normal glucose } \\
\text { tolerance, no viral hepatitis, no alcohol ; } \\
4 \text { years; liver ultrasonography }\end{array}$ & $\begin{array}{l}\text { Fasting glucose } \geq 7.0 \\
\mathrm{mmol} / 1 \text { or } 2-\mathrm{h} \text { glucose } \\
\geq 11.1 \mathrm{mmol} / 1 \text { on } 75-\mathrm{g} \\
\text { OGTT }\end{array}$ & $\begin{array}{l}\mathrm{n}=109 \text { incident cases } \\
1.8 \% \text { vs. } 8.1 \%\end{array}$ & $\begin{array}{l}\text { Age and BMI (in the } \\
\text { whole cohort analysis); } \\
\text { age, BMI, smoking, } \\
\text { blood pressure, physical } \\
\text { activity, duration of } \\
\text { follow-up and prevalence } \\
\text { of metabolic syndrome } \\
\text { (in the nested case- } \\
\text { control analysis) }\end{array}$ & $\begin{array}{l}\text { NAFLD was independently } \\
\text { associated with incident diabetes } \\
\text { both in the whole cohort (aHR } \\
5.50,95 \% \text { CI } 3.6-8.5 \text { ) and in the } \\
\text { nested case-control analysis } \\
\text { (aHR } 4.60,95 \% \text { CI } 3.0-6.9 \text {, } \\
\text { P<0.001) }\end{array}$ \\
\hline $\begin{array}{l}\text { Kim et al. } \\
2008 \text { [12] }\end{array}$ & $\begin{array}{l}\text { Retrospective cohort study } \\
\mathrm{n}=5,372 \text { nondiabetic South Korean } \\
\text { subjects, no viral hepatitis or excessive } \\
\text { alcohol; } 5 \text { years; liver ultrasonography }\end{array}$ & $\begin{array}{l}\text { Fasting glucose } \geq 7.0 \\
\text { mmol/l, clinical history or } \\
\text { drug treatment }\end{array}$ & $\begin{array}{l}\mathrm{n}=234 \text { incident cases } \\
2.3 \% \text { vs. } 8.5 \%\end{array}$ & $\begin{array}{l}\text { Age, sex, BMI, family } \\
\text { history of diabetes, } \\
\text { smoking, fasting glucose, } \\
\text { HDL-cholesterol, } \\
\text { triglycerides, serum ALT }\end{array}$ & $\begin{array}{l}\text { NAFLD was independently } \\
\text { associated with incident diabetes } \\
\text { (aHR 1.51,95\% CI 1.04-2.2, } \\
\text { P=0.034). Moderate/severe } \\
\text { NAFLD had higher HRs } v s . \text { mild } \\
\text { NAFLD. Exclusion of drinkers } \\
\text { did not attenuate the association }\end{array}$ \\
\hline $\begin{array}{l}\text { Yamada et } \\
\text { al. } 2010 \\
{[13]}\end{array}$ & $\begin{array}{l}\text { Retrospective cohort study } \\
\mathrm{n}=12,375 \text { nondiabetic Japanese subjects } \\
\text { without hepatic diseases and viral } \\
\text { hepatitis; } 5 \text { years; liver ultrasonography }\end{array}$ & $\begin{array}{l}\text { Fasting glucose } \geq 7.0 \\
\text { mmol/1, clinical history or } \\
\text { drug treatment }\end{array}$ & $\begin{array}{l}\mathrm{n}=96 \text { incident cases of } \\
\text { diabetes; } 0.5 \% \text { vs. } \\
2.5 \% \\
\mathrm{n}=728 \text { incident IFG } \\
\text { cases; } 4 \% \text { vs. } 10 \%\end{array}$ & $\begin{array}{l}\text { Age, sex, BMI, family } \\
\text { history of diabetes, } \\
\text { hypertension, alcohol } \\
\text { intake, smoking status }\end{array}$ & $\begin{array}{l}\text { NAFLD was independently } \\
\text { associated with incident IFG } \\
\text { and/or diabetes in both sexes } \\
\text { (aOR } 1.91,95 \% \text { CI } 1.6-2.3 \text { in } \\
\text { men and OR } 2.15,95 \% \text { CI } 1.5- \\
3.0 \text { in women) }\end{array}$ \\
\hline
\end{tabular}




\begin{tabular}{|c|c|c|c|c|c|}
\hline $\begin{array}{l}\text { Bae et al. } \\
2011[14]\end{array}$ & $\begin{array}{l}\text { Retrospective cohort study } \\
\mathrm{n}=7,849 \text { nondiabetic South Korean } \\
\text { subjects; } 5 \text { years; liver ultrasonography }\end{array}$ & $\begin{array}{l}\text { Fasting glucose } \geq 7.0 \\
\text { mmol/l or } \mathrm{HbA} 1 \mathrm{c} \geq 6.5 \%, \\
\text { clinical history or drug } \\
\text { treatment }\end{array}$ & $\begin{array}{l}\mathrm{n}=435 \text { incident cases } \\
3.7 \% \text { vs. } 9.9 \%\end{array}$ & $\begin{array}{l}\text { Age, sex, BMI, } \\
\text { triglycerides, HDL } \\
\text { cholesterol, systolic } \\
\text { blood pressure, smoking } \\
\text { status, physical activity, } \\
\text { alcohol intake, IFG } \\
\text { status }\end{array}$ & $\begin{array}{l}\text { NAFLD was independently } \\
\text { associated with incident diabetes } \\
(\text { aHR } 1.33,95 \% \text { CI } 1.1-1.7, \\
\text { P<0.05). This association was } \\
\text { much stronger in pre-existing } \\
\text { IFG }\end{array}$ \\
\hline $\begin{array}{l}\text { Park et al. } \\
2012 \text { [15] }\end{array}$ & $\begin{array}{l}\text { Prospective cohort study (health check- } \\
\text { up) } \\
n=25,232 \text { nondiabetic South Korean men, } \\
\text { no viral hepatitis,or excessive alcohol; } 5 \\
\text { years; liver ultrasonography }\end{array}$ & $\begin{array}{l}\text { Fasting glucose } \geq 7.0 \\
\text { mmol } / 1, \text { HbA } 1 \mathrm{c} \geq 6.5 \% \\
\text { clinical history }\end{array}$ & $\begin{array}{l}\mathrm{n}=2,108 \text { incident cases } \\
7 \% \text { in no-steatosis vs. } \\
9.8 \% \text { in mild steatosis } \\
\text { vs. } 17.8 \% \text { in moderate- } \\
\text { severe steatosis }\end{array}$ & $\begin{array}{l}\text { Age, waist } \\
\text { circumference, HDL } \\
\text { cholesterol, triglycerides, } \\
\text { systolic blood pressure, } \\
\text { C-reactive protein, } \\
\text { HOMA-IR, serum } \\
\text { creatinine, family history } \\
\text { of diabetes, physical } \\
\text { exercise, metabolic } \\
\text { syndrome }\end{array}$ & $\begin{array}{l}\text { NAFLD was independently } \\
\text { associated with incident diabetes; } \\
\text { the HRs }(95 \% \mathrm{CI}) \text { were increased } \\
\text { in mild steatosis }(1.09 ; 0.8-1.5) \\
\text { and in moderate/severe steatosis } \\
(1.73 ; 1.0-3.0) v s . \text { no-steatosis }\end{array}$ \\
\hline $\begin{array}{l}\text { Sung et al. } \\
2012[16]\end{array}$ & $\begin{array}{l}\text { Retrospective cohort study } \\
\mathrm{n}=12,853 \text { nondiabetic South Korean } \\
\text { subjects; } 5 \text { years; liver ultrasonography }\end{array}$ & $\begin{array}{l}\text { Fasting glucose } \geq 7.0 \\
\text { mmol/1, clinical history or } \\
\text { drug treatment }\end{array}$ & $\begin{array}{l}\mathrm{n}=223 \text { incident cases } \\
0.8 \% \text { vs. } 4.3 \%\end{array}$ & $\begin{array}{l}\text { Age, sex, BMI, } \\
\text { educational status, } \\
\text { smoking, physical } \\
\text { activity, alcohol intake, } \\
\text { HOMA-IR, serum } \\
\text { triglycerides, serum ALT }\end{array}$ & $\begin{array}{l}\text { The clustering of increased } \\
\text { HOMA-IR, overweight/obesity, } \\
\text { and NAFLD markedly increases } \\
\text { the odds of developing diabetes, } \\
\text { with effects independent of each } \\
\text { other and of confounding factors. } \\
\text { NAFLD was associated with } \\
\text { incident diabetes (aOR 2.42, } 95 \% \\
\text { CI } 1.7-3.4, \mathrm{P}<0.001)\end{array}$ \\
\hline $\begin{array}{l}\text { Kasturiratn } \\
\text { e et al. } \\
2013[17]\end{array}$ & $\begin{array}{l}\text { Retrospective cohort study } \\
\mathrm{n}=2,276 \text { nondiabetic Sri Lankan } \\
\text { individuals, no viral hepatitis or excessive } \\
\text { alcohol consumption; } 3 \text { years; liver } \\
\text { ultrasonography }\end{array}$ & $\begin{array}{l}\text { Fasting glucose } \geq 7.0 \\
\text { mmol/1, clinical history or } \\
\text { drug treatment }\end{array}$ & $\begin{array}{l}\mathrm{n}=242 \text { incident cases } \\
10.5 \% \text { vs. } 19.7 \%\end{array}$ & $\begin{array}{l}\text { Age, sex, family history } \\
\text { of diabetes, BMI, waist } \\
\text { circumference, } \\
\text { hypertension, } \\
\text { dyslipidemia, IFG status, } \\
\text { serum ALT }\end{array}$ & $\begin{array}{l}\text { NAFLD was independently } \\
\text { associated with incident diabetes } \\
\text { (aHR } 1.64,95 \% \text { CI 1.2-2.2). } \\
\text { NAFLD was the only predictor } \\
\text { of incident diabetes in those with } \\
\text { IFG at baseline }\end{array}$ \\
\hline $\begin{array}{l}\text { Chang et al. } \\
2013[18]\end{array}$ & $\begin{array}{l}\text { Prospective cohort study (health check- } \\
\text { up) } \\
\mathrm{n}=38,291 \text { nondiabetic South Korean } \\
\text { subjects, no known liver diseases, viral } \\
\text { hepatitis or excessive alcohol; } 5 \text { years; } \\
\text { liver ultrasonography }\end{array}$ & $\begin{array}{l}\text { Fasting glucose } \geq 7.0 \\
\mathrm{mmol} / 1, \mathrm{HbA} 1 \mathrm{c} \geq 6.5 \%, \text { or } \\
\text { drug treatment }\end{array}$ & $\begin{array}{l}\mathrm{n}=2,025 \text { incident cases } \\
3.5 \% \text { in no-NAFLD } v s . \\
7.4 \% \text { in NAFLD with } \\
\text { low fibrosis score } \\
\text { (NFS) } v s .15 .3 \% \text { in } \\
\text { NAFLD with } \\
\text { intermediate/high NFS }\end{array}$ & $\begin{array}{l}\text { Age, sex, smoking status, } \\
\text { alcohol intake, regular } \\
\text { exercise, family history } \\
\text { of diabetes, cholesterol, } \\
\text { triglycerides, HDL } \\
\text { cholesterol, HOMA-IR, } \\
\text { C-reactive protein }\end{array}$ & $\begin{array}{l}\text { The aHRs (95\% CI) for incident } \\
\text { diabetes in NAFLD with low } \\
\text { NFS and NAFLD with } \\
\text { intermediate or high NFS vs. no } \\
\text { NAFLD were } 2.0(1.8-2.2) \text { and } \\
4.74 \text { (3.7-6.1), respectively. This } \\
\text { association remained significant } \\
\text { in subjects with fasting glucose }\end{array}$ \\
\hline
\end{tabular}




\begin{tabular}{|c|c|c|c|c|c|}
\hline & & & & & $\begin{array}{l}<100 \mathrm{mg} / \mathrm{dl} \text { and with } \mathrm{HbA} 1 \mathrm{c} \\
<5.8 \%\end{array}$ \\
\hline $\begin{array}{l}\text { Choi et al. } \\
2013 \text { [19] }\end{array}$ & $\begin{array}{l}\text { Retrospective cohort study } \\
\mathrm{n}=7,849 \text { nondiabetic South Korean } \\
\text { subjects, no viral hepatitis or excessive } \\
\text { alcohol; } 4 \text { years; liver ultrasonography }\end{array}$ & $\begin{array}{l}\text { Fasting glucose } \geq 7.0 \\
\mathrm{mmol} / 1, \mathrm{HbA} 1 \mathrm{c} \geq 6.5 \%, \text { or } \\
\text { drug treatment }\end{array}$ & $\begin{array}{l}\mathrm{n}=435 \text { incident cases } \\
3.5 \% \text { in controls vs. } \\
4.6 \% \text { in the increased } \\
\text { ALT vs. } 7.3 \% \text { in the } \\
\text { steatosis vs. } 11.8 \% \text { in } \\
\text { the combined } \\
\text { abnormality group }\end{array}$ & $\begin{array}{l}\text { Age, sex, BMI, systolic } \\
\text { blood pressure, } \\
\text { triglycerides, HDL } \\
\text { cholesterol, IFG status, } \\
\text { physical activity, } \\
\text { smoking, alcohol } \\
\text { consumption }\end{array}$ & $\begin{array}{l}\text { The HRs }(95 \% \text { CI) of incident } \\
\text { diabetes was stepwise increased } \\
\text { in the elevated ALT, the } \\
\text { steatosis, and the combined } \\
\text { abnormality group. Subjects in } \\
\text { the combined abnormality group } \\
\text { had a significantly increased aHR } \\
\text { of } 1.64 \text { (95\% CI } 1.3-2.1 \text {, } \\
\mathrm{P}<0.001)\end{array}$ \\
\hline $\begin{array}{l}\text { Sung et al. } \\
2013 \text { [20] }\end{array}$ & $\begin{array}{l}\text { Retrospective cohort study } \\
\mathrm{n}=13,218 \text { nondiabetic South Korean } \\
\text { subjects; } 5 \text { years; liver ultrasonography }\end{array}$ & $\begin{array}{l}\text { Fasting glucose } \geq 7.0 \\
\text { mmol/l, clinical history or } \\
\text { drug treatment }\end{array}$ & $\begin{array}{l}\mathrm{n}=234 \text { incident cases } \\
0.8 \% \text { in no steatosis vs. } \\
3.4 \% \text { in mild steatosis } \\
\text { vs. } 12.3 \% \text { in moderate- } \\
\text { severe steatosis }\end{array}$ & $\begin{array}{l}\text { Age, sex, BMI, glucose, } \\
\text { insulin, triglycerides, } \\
\text { HDL cholesterol, systolic } \\
\text { blood pressure, alcohol } \\
\text { use, smoking, physical } \\
\text { activity, change in BMI } \\
\text { between baseline and } \\
\text { follow-up, serum ALT, } \\
\text { AST, GGT }\end{array}$ & $\begin{array}{l}\text { Fatty liver resolved in } 828, \\
\text { developed in } 1640 \text {, and } \\
\text { progressed from mild to } \\
\text { moderate/severe in } 324 \text { people. } \\
\text { Resolution was not associated } \\
\text { with risk of incident diabetes } \\
\text { (aOR } 0.95,95 \% \text { CI } 0.5-1.9 \text { ). } \\
\text { Development of new fatty liver } \\
\text { was associated with incident } \\
\text { diabetes (aOR } 2.49,95 \% \text { CI } 1.5- \\
4.1, \text { P }<0.001 \text { ). In individuals } \\
\text { with worsening fatty liver (from } \\
\text { mild to moderate/severe), } \\
\text { diabetes risk markedly increased } \\
\text { (aOR } 6.13,95 \% \text { CI } 2.6-14.7 \text {, } \\
\mathrm{P}<0.001 \text { vs. subjects with fatty } \\
\text { liver resolution) }\end{array}$ \\
\hline $\begin{array}{l}\text { Yamazaki } \\
\text { et al. } 2015 \\
{[21]}\end{array}$ & $\begin{array}{l}\text { Retrospective cohort study } \\
\text { n=3,074 nondiabetic Japanese subjects, } \\
\text { no viral hepatitis or excessive alcohol; } \\
11.3 \text { years; liver ultrasonography }\end{array}$ & $\begin{array}{l}\text { Fasting glucose } \geq 7.0 \\
\text { mmol } / 1, \text { HbA } 1 \mathrm{c} \geq 6.5 \%, \\
\text { clinical history or drug } \\
\text { treatment }\end{array}$ & $\begin{array}{l}\mathrm{n}=189 \text { incident cases } \\
3.1 \text { vs. } 16.1 \%\end{array}$ & $\begin{array}{l}\text { Age, sex, family history } \\
\text { of diabetes, BMI, IFG } \\
\text { status, dyslipidemia, } \\
\text { hypertension, physical } \\
\text { exercise }\end{array}$ & $\begin{array}{l}\text { NAFLD was independently } \\
\text { associated with incident diabetes } \\
\text { (aOR 2.37, 95\% CI 1.6-3.5, } \\
\text { P<0.001). NAFLD improvement } \\
\text { was associated with a reduction } \\
\text { of incident diabetes (aOR } 0.27 \text {, } \\
95 \% \text { CI } 0.1-0.6, \mathrm{P}<0.001 \text { ) }\end{array}$ \\
\hline $\begin{array}{l}\text { Fukuda et } \\
\text { al. } 2015 \\
{[22]}\end{array}$ & $\begin{array}{l}\text { Retrospective cohort study } \\
\mathrm{n}=4,629 \text { nondiabetic Japanese subjects, } \\
\text { no liver disease or excessive alcohol; } \\
12.8 \text { years; liver ultrasonography }\end{array}$ & $\begin{array}{l}\text { Fasting glucose } \geq 7.0 \\
\mathrm{mmol} / 1, \mathrm{HbA} 1 \mathrm{c} \geq 6.5 \%, \text { or } \\
\text { drug treatment }\end{array}$ & $\begin{array}{l}\mathrm{n}=351 \text { incident cases } \\
3.2 \% \text { in non- } \\
\text { overweight, no- } \\
\text { NAFLD vs. } 14.4 \% \text { in } \\
\text { non-overweight }\end{array}$ & $\begin{array}{l}\text { Age, sex, family history } \\
\text { of diabetes, alcohol } \\
\text { intake, smoking, regular } \\
\text { exercise, HbA1c }\end{array}$ & $\begin{array}{l}\text { aHRs for incident diabetes } v s . \\
\text { non-overweight without NAFLD } \\
\text { group were: } 3.59 \text { (95\%CI } 2.14- \\
5.76 \text { ) in the non-overweight with } \\
\text { NAFLD group, } 1.99 \text { (95\%CI }\end{array}$ \\
\hline
\end{tabular}




\begin{tabular}{|c|c|c|c|c|c|}
\hline & & & $\begin{array}{l}\text { NAFLD vs. } 8.0 \% \text { in } \\
\text { overweight no-NAFLD } \\
\text { vs. } 26.4 \% \text { in } \\
\text { overweight NAFLD }\end{array}$ & & $\begin{array}{l}\text { 1.5-2.7) in the overweight } \\
\text { without NAFLD group and } 6.77 \\
\text { (95\%CI 5.2-8.9) in the } \\
\text { overweight with NAFLD group }\end{array}$ \\
\hline $\begin{array}{l}\text { Ming et al. } \\
2015 \text { [23] }\end{array}$ & $\begin{array}{l}\text { Retrospective cohort study } \\
\mathrm{n}=508 \text { nondiabetic Chinese subjects, no } \\
\text { chronic liver diseases or excessive } \\
\text { alcohol; } 5 \text { years; liver ultrasonography }\end{array}$ & $\begin{array}{l}\text { Fasting glucose } \geq 7.0 \\
\mathrm{mmol} / \mathrm{l}, 2-\mathrm{h} \text { glucose } \geq 11.1 \\
\mathrm{mmol} / \mathrm{l} \text { on } 75-\mathrm{g} \text { OGTT or } \\
\text { drug treatment }\end{array}$ & $\begin{array}{l}n=20 \text { incident cases } \\
2.4 \% \text { vs. } 10.3 \%\end{array}$ & $\begin{array}{l}\text { age, sex, educational } \\
\text { level, smoking, alcohol } \\
\text { intake, physical activity, } \\
\text { family history of } \\
\text { diabetes, BMI, blood } \\
\text { pressure, fasting glucose, } \\
\text { 2-h glucose, } \\
\text { triglycerides, HDL } \\
\text { cholesterol }\end{array}$ & $\begin{array}{l}\text { NAFLD was independently } \\
\text { associated with incident diabetes } \\
\text { (aHR } 4.46,95 \% \text { CI } 1.9-10.7 \text {, } \\
\text { P<0.001) but not with incident } \\
\text { pre-diabetes (aHR } 1.64,95 \% \text { CI } \\
0.97-2.8 \text { ) }\end{array}$ \\
\hline $\begin{array}{l}\text { Li et al. } \\
2015 \text { [24] }\end{array}$ & $\begin{array}{l}\text { Retrospective cohort study } \\
\mathrm{n}=4,736 \text { nondiabetic Chinese subjects, no } \\
\text { viral hepatitis or excessive alcohol ; } 4 \\
\text { years; liver ultrasonography }\end{array}$ & $\begin{array}{l}\text { Fasting glucose } \geq 7.0 \\
\text { mmol/1, clinical history or } \\
\text { drug treatment }\end{array}$ & $\begin{array}{l}\mathrm{n}=380 \text { incident cases } \\
4.1 \text { vs. } 17.4 \%\end{array}$ & $\begin{array}{l}\text { Age, sex, blood pressure, } \\
\text { lipids, ALT, uric acid, } \\
\text { creatinine }\end{array}$ & $\begin{array}{l}\text { NAFLD was independently } \\
\text { associated with incident diabetes } \\
\text { (aHR } 3.37,95 \% \text { CI } 2.4-4.3 \text { ) }\end{array}$ \\
\hline $\begin{array}{l}\text { Shah et al. } \\
2015 \text { [25] }\end{array}$ & $\begin{array}{l}\text { Prospective cohort study } \\
\mathrm{n}=3,153 \text { nondiabetic individuals from the } \\
\text { Multi-Ethnic Study of Atherosclerosis; } \\
9.1 \text { years; liver computed tomography }\end{array}$ & $\begin{array}{l}\text { Fasting glucose } \geq 7.0 \\
\text { mmol/l, clinical history or } \\
\text { drug treatment }\end{array}$ & $\mathrm{n}=216$ incident cases & $\begin{array}{l}\text { Age, sex, race, family } \\
\text { history of diabetes, BMI, } \\
\text { waist circumference, } \\
\text { systolic blood pressure, } \\
\text { triglycerides, HDL } \\
\text { cholesterol, glucose, C- } \\
\text { reactive protein, } \\
\text { exercise, statin use }\end{array}$ & $\begin{array}{l}\text { NAFLD (defined as } 1^{\text {st }} \text { quartile } \\
\text { of hepatic attenuation on } \\
\text { computed tomography) was } \\
\text { independently associated with } \\
\text { incident diabetes (aHR } 2.06,95 \% \\
\text { CI } 1.5-2.8, \mathrm{P}<0.001 \text { ) }\end{array}$ \\
\hline
\end{tabular}

Abbreviations: ALT, alanine aminotransferase; AST, aspartate aminotransferase; BMI, body mass index; CI, confidence interval; GGT, gamma-glutamyltransferase; HDL, high-density lipoprotein; HOMA-IR, homeostasis model assessment-insulin resistance; IFG, impaired fasting glycaemia; aHR, adjusted hazard ratio; aOR, adjusted odds ratio. 
Table 2 - Pharmacologic treatments of NAFLD, with potential impact on glucose metabolism, tested in randomized clinical trials with histologic outcomes.

\begin{tabular}{|c|c|c|c|c|}
\hline $\begin{array}{l}\text { Author, Year } \\
\text { [Ref] }\end{array}$ & $\begin{array}{l}\text { Treatment, Number of cases. } \\
\text { Patients with diabetes }\end{array}$ & $\begin{array}{l}\text { Treatment } \\
\text { Duration }\end{array}$ & $\begin{array}{l}\text { Experimental drug effect on liver disease at } \\
\text { histology }\end{array}$ & $\begin{array}{l}\text { Effects on glucose metabolism and } \\
\text { diabetes parameters }\end{array}$ \\
\hline $\begin{array}{l}\text { Bugianesi et al. } \\
2005[72]\end{array}$ & $\begin{array}{l}\text { MET } 2 \text { g, } 55 \text {; Vit. E, } 28 \text {; Diet, } \\
\text { 27. Only } 10 \text { cases with T2DM }\end{array}$ & 12 months & $\begin{array}{l}\text { Vit. E and Diet did not produce histological } \\
\text { effects and were combined as controls. MET } \\
\text { decreased liver fat }(\mathrm{P}<0.001) \text {, fibrosis and } \\
\text { necroinflammation }(\mathrm{P}=0.012) \text { at follow-up vs. } \\
\text { controls }\end{array}$ & $\begin{array}{l}\text { On average MET decreased fasting glucose } \\
\text { by } 10 \mathrm{mg} / \mathrm{dL} \text { and insulin by } 4.5 \mathrm{mU} / \mathrm{mL} v \mathrm{~s} \text {. a } \\
\text { limited decrease of only } 5 \mathrm{mg} / \mathrm{dL} \text { and } 1.5 \\
\mathrm{mU} / \mathrm{mL} \text { in other arms, respectively. }\end{array}$ \\
\hline $\begin{array}{l}\text { Belfort et al. } 2006 \\
\text { [73] }\end{array}$ & $\begin{array}{l}\text { PIO } 45 \mathrm{mg}, 29 \text {; counselling, } \\
\text { 25. } 55 \text { with IGT/T2DM }\end{array}$ & 6 months & $\begin{array}{l}\text { PIO significantly improved steatosis, } \\
\text { inflammation, ballooning and fibrosis } v s . \\
\text { counselling }(\mathrm{P}<0.01 \text { for all })\end{array}$ & $\begin{array}{l}\text { PIO decreased fasting glucose by } 20 \mathrm{mg} / \mathrm{dL} \text {, } \\
\mathrm{A} 1 \mathrm{c} \text { by } 0.7 \% \text { and fasting insulin by } 5 \\
\mathrm{mU} / \mathrm{mL} \text { vs. unchanged in } \mathrm{PL}(\mathrm{P}<0.01)\end{array}$ \\
\hline $\begin{array}{l}\text { Ratziu et al. } 2008 \\
\text { [74] } \\
\text { FLIRT trial }\end{array}$ & $\begin{array}{l}\text { RSG } 8 \text { mg, 32; PL, } 31.16 \\
\text { with T2DM }\end{array}$ & 12 months & $\begin{array}{l}\text { RSG improved steatosis }(\mathrm{P}=0.014) \text {, without } \\
\text { differences in fibrosis or necroinflammation }\end{array}$ & $\begin{array}{l}\text { RSG decreased glucose by } 16 \mathrm{mg} / \mathrm{dL}, \mathrm{A} 1 \mathrm{c} \\
\text { by } 0.2 \% \text {, insulin by } 5.5 \mathrm{mU} / \mathrm{mL} \text { vs. } \\
\text { unchanged or increased in PL }\end{array}$ \\
\hline $\begin{array}{l}\text { Aithal et al. } 2008 \\
\text { [75] }\end{array}$ & $\begin{array}{l}\text { PIO } 30 \mathrm{mg}, 37 ; \text { PL, } 37 . \text { Cases } \\
\text { with T2DM were excluded }\end{array}$ & 12 months & $\begin{array}{l}\text { PIO decreased necroinflammation }(\mathrm{PIO} v s . \mathrm{PL} \text {, } \\
0.005) \text { and Mallory-Denk bodies }(\mathrm{P}=0.004)\end{array}$ & $\begin{array}{l}\text { High PIO decreased glucose by } 7 \mathrm{mg} / \mathrm{dL} \text {, } \\
\text { A1c by } 0.2 \% \text { vs. }+7 \mathrm{mg} / \mathrm{dL} \text { and }+0.1 \% \text { in PL } \\
(\mathrm{P}<0.02)\end{array}$ \\
\hline $\begin{array}{l}\text { Haukeland et al. } \\
2009 \text { [76] }\end{array}$ & $\begin{array}{l}\text { MET } 2.5-3 \mathrm{~g}, 24 \text {; Controls, } \\
\text { 24. All cases had pre-diabetes } \\
\text { or T2DM }\end{array}$ & 6 months & $\begin{array}{l}\text { No differences in steatosis, necro-inflammation } \\
\text { or fibrosis were observed between MET and } \\
\text { controls }\end{array}$ & $\begin{array}{l}\text { MET produced a moderate reduction of } \\
\text { glucose }(-5 \mathrm{mg} / \mathrm{dL}) \text { and } \mathrm{HbA} 1 \mathrm{c}(-0.2 \%)\end{array}$ \\
\hline $\begin{array}{l}\text { Shields et al. } 2009 \\
\text { [77] }\end{array}$ & $\begin{array}{l}\text { MET } 0.5-1 \text { g. } 9 \text {; Counselling, } \\
\text { 10. T2DM subjects were } \\
\text { excluded }\end{array}$ & 12 months & $\begin{array}{l}\text { MET did not change NAFLD activity score and } \\
\text { its individual components }\end{array}$ & $\begin{array}{l}\text { Improved HOMA-IR values in all patients, } \\
\text { without differences between groups }\end{array}$ \\
\hline $\begin{array}{l}\text { Ratziu et al. } 2010 \\
\text { [78] } \\
\text { FLIRT } 2 \text { trial }\end{array}$ & $\begin{array}{l}\text { RSG, } 53 \text { (RSG-RSG, 25; PL- } \\
\text { RSG, 28). Open-label } \\
\text { extension of FLIRT [72] }\end{array}$ & 24 months & $\begin{array}{l}\text { RSG did not produce any additional histological } \\
\text { improvement beyond the } 1 \text { year liver biopsy }\end{array}$ & $\begin{array}{l}\text { No changes in biochemistry were observed } \\
\text { during the extension period }\end{array}$ \\
\hline $\begin{array}{l}\text { Sanyal et al. } 2010 \\
\text { [79] } \\
\text { PIVENS trial }\end{array}$ & $\begin{array}{l}\text { PIO } 30 \mathrm{mg}, 87 \text {; Vit. E, 84; PL, } \\
\text { 83. All subjects had NASH. } \\
\text { Patients with diabetes were } \\
\text { excluded }\end{array}$ & 96 weeks & $\begin{array}{l}\text { Both drugs were better than } \mathrm{PL} \text { on steatosis } \\
(\mathrm{P}<0.001) \text { and lobular inflammation }(\mathrm{P}<0.01) \text {, not } \\
\text { on fibrosis. Higher rates of NASH resolution } \\
\text { were reported on both experimental drugs }\end{array}$ & $\begin{array}{l}\text { Improved fasting glucose levels and HOMA- } \\
\text { IR were observed on PIO vs. PL }\end{array}$ \\
\hline
\end{tabular}




\begin{tabular}{|c|c|c|c|c|}
\hline $\begin{array}{l}\text { Lavine et al. } 2011 \\
{[80]} \\
\text { TONIC trial }\end{array}$ & $\begin{array}{l}\text { Paediatric study: Vit. E } 800 \\
\text { UI, } 57 \text {; MET } 1 \mathrm{~g}, 57 ; \text { PL, } 58 . \\
\text { No subjects had diabetes at } \\
\text { entry }\end{array}$ & 96 weeks & $\begin{array}{l}\text { NAS score improved in all groups. Higher rates } \\
\text { of NASH resolution were observed on Vit E in } \\
\text { subjects with NASH at entry ( } 58 \% \text { vs. } 28 \% \text {; } \\
\mathrm{P}=0.006) \text {. Only ballooning improved on MET }\end{array}$ & $\begin{array}{l}\text { No remarkable differences in the time- } \\
\text { courses of fasting glucose or HOMA-IR } \\
\text { were reported between groups }\end{array}$ \\
\hline $\begin{array}{l}\text { Neuschwander- } \\
\text { Tetri al. } 2014 \text { [35] } \\
\text { FLINT trial }\end{array}$ & $\begin{array}{l}\text { OCA } 25 \mathrm{mg}, 141 ; \text { PL } 142 . \\
\text { Trial stopped for superiority: } \\
\text { OCA, 102; PL, } 98.52 \% \text { with } \\
\text { T2DM }\end{array}$ & 72 weeks & $\begin{array}{l}\text { The study was discontinued early for efficacy: } \\
\text { improved histology (steatosis, lobular } \\
\text { inflammation, ballooning, fibrosis) in } 45 \% \text { OCA } \\
\text { vs. } 21 \% \text { PL. Definite NASH resolution, } 22 \% \text { vs. } \\
13 \% \text { (P=0.08) }\end{array}$ & $\begin{array}{l}\text { No changes in fasting glucose between } \\
\text { groups, but OCA was associated with } \\
\text { increased insulin levels }(\mathrm{P}=0.02 \mathrm{vs} . \mathrm{PL}) \text { and } \\
\text { HOMA-IR }\end{array}$ \\
\hline $\begin{array}{l}\text { Armstrong et al. } \\
2015[58] \\
\text { LEAN program }\end{array}$ & $\begin{array}{l}\text { LIRA } 1.8 \mathrm{mg}, 26 ; \mathrm{PL}, 26.33 \% \\
\text { of cases had T2DM and were } \\
\text { on chronic MET (+SULFA in } \\
4 \% \text { ) }\end{array}$ & $\begin{array}{l}48 \text { weeks } \\
\text { (extension to } \\
72 \text { weeks) }\end{array}$ & $\begin{array}{l}\text { LIRA was associated with higher rates of } \\
\text { improvement in steatosis, ballooning and fibrosis. } \\
\text { NASH resolution occurred in } 39 \% \text { of cases on } \\
\text { LIRA vs. } 9 \% \text { in } \mathrm{PL} ; \mathrm{P}=0.02 \text { ) }\end{array}$ & $\begin{array}{l}\text { Weight loss, } 5.3 \mathrm{~kg} \text { on LIRA vs. } 0.6 \text { on } \mathrm{PL} \\
(\mathrm{P}=0.003) . \text { Significantly reduced glucose }(- \\
18 \mathrm{mg} / \mathrm{dL}), \mathrm{A} 1 \mathrm{c}(-0.5 \%) \text { vs. } \mathrm{PL}(\mathrm{P}=0.005 \text { and } \\
\mathrm{P}=0.03 \text {, respectively })\end{array}$ \\
\hline
\end{tabular}

Abbreviations: A1c, glycosylated haemoglobin; HOMA-IR, homeostasis model assessment-insulin resistance; IGT, impaired glucose tolerance; LIRA, liraglutide; MET, metformin; OCA, obeticholic acid; PIO, pioglitazone; PL, placebo; RSG, rosiglitazone; T2DM, type 2 diabetes mellitus; Vit E, vitamin E. 


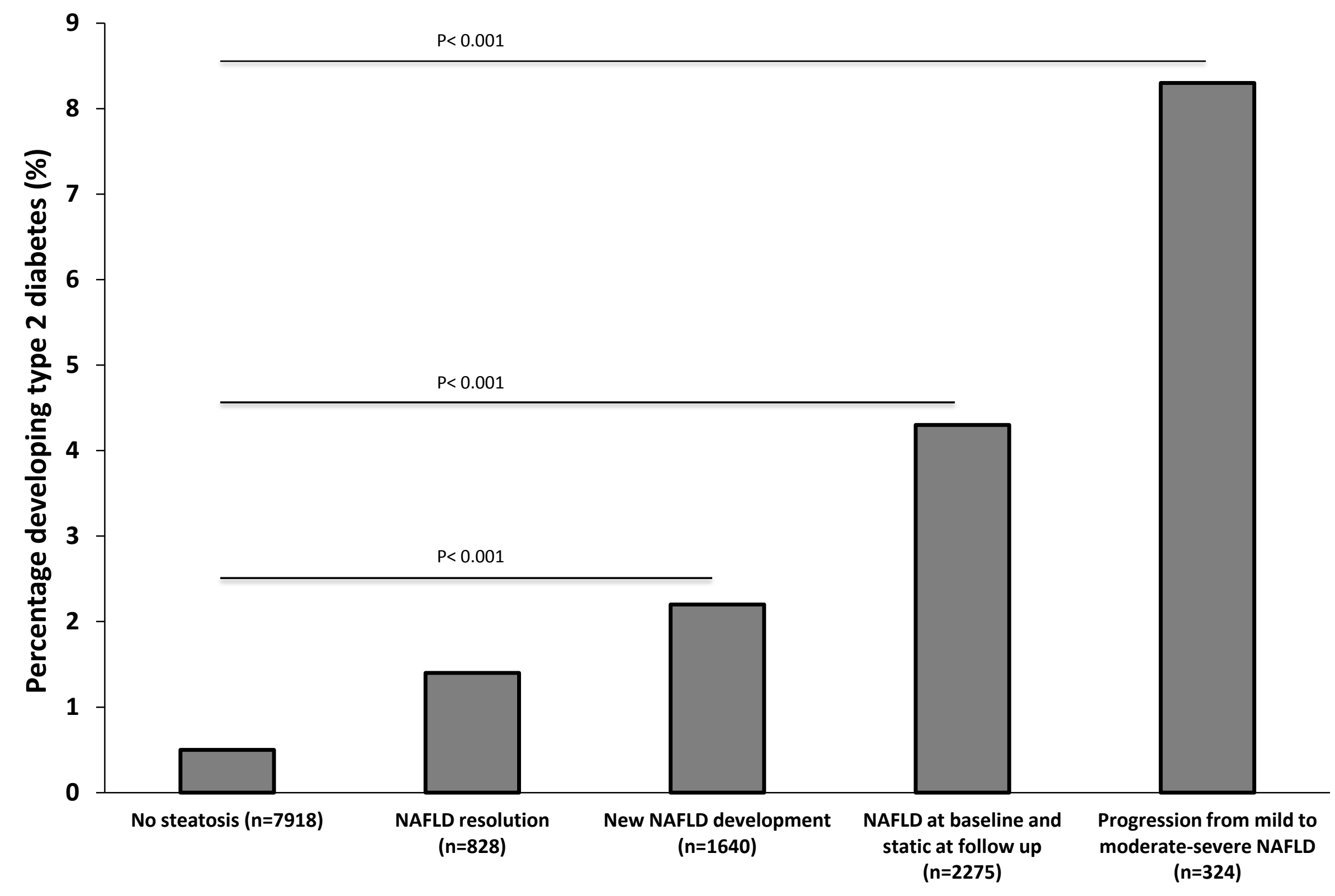

Change in fatty liver status on ultrasound over 5 years 
